\title{
Aspirations and food security in rural Ethiopia
}

\author{
Daniel Ayalew Mekonnen $^{1}$ (D) $\cdot$ Nicolas Gerber $^{1}$
}

Received: 15 April 2016/Accepted: 24 January 2017 /Published online: 11 March 2017

(C) The Author(s) 2017. This article is published with open access at Springerlink.com

\begin{abstract}
Despite some improvements in recent years, poverty and food insecurity remain widespread and the main challenges in Ethiopia. Much of the empirical literature focuses on identifying the resource-related constraints for farmers to achieve food security and move out of poverty, with little attention paid to 'internal' or psychological factors such as aspirations. Using individual and household data collected in rural Ethiopia, we examined if aspirations were strongly associated with well-being outcomes, in our case food security, as posited in the theoretical framework of aspirations failure. We found that aspirations of the household head were positively and strongly associated with various triangulating measures of household food security including per-capita calorie consumption, the food consumption score (FCS), the household dietary diversity score (HDDS), and negatively associated with the household food insecurity access scale (HFIAS). In contrast, results suggest that the aspirations of the spouse of the household head are negatively associated with per-capita calorie consumption and FCS. We discuss the channels through which aspirations may affect food security and the avenues for future research.
\end{abstract}

Key words Aspirations $\cdot$ Farm households · Food security · Ethiopia

Daniel Ayalew Mekonnen

dameko@uni-bonn.de

Nicolas Gerber

ngerber@uni-bonn.de

1 Center for Development Research (ZEF), University of Bonn, Walter-Flex-Str. 3, D-53113 Bonn, Germany

\section{Introduction}

Despite some improvements in recent years, poverty and food insecurity remain widespread and the main challenges in Ethiopia. These challenges are further exacerbated by climatic shocks such as failure of rainfall, which adversely affect agriculture and allied activities, the main livelihood activities for the rural population. ${ }^{1}$ Following the failure of rainfall during the 2015 agricultural seasons, estimates suggest that about 10.1 million people required emergency food assistance as of December 2015 (EHRD 2016). Poverty persistence had long been recognised as a major contributing factor for the continuing vulnerability of the food insecure groups and this has led the government, jointly with development partners, to implement a social safety net program (PSNP) since 2005. This program aims at "smoothing consumption, reducing risks the poor face and protecting their assets" (GFDRE 2009). In 2012, the PSNP reached over 7.6 million people and the program is complemented by a household asset building program (HABP), which provides food insecure households with financial services and technical support to strengthen their production systems by diversifying income sources, and increasing productive assets so as to improve their productivity (World Bank 2013).

Notwithstanding the potential benefits associated with policies such as the PSNP, the alleged benefits can be realized only under a set of conditions. For example, the recent weather-related shocks highlight the level of vulnerability of the poor despite such programs. In addition, while earlier evaluations of the PSNP (e.g. Gilligan et al. 2009; Berhane et al. 2011, 2014; Coll-Black et al. 2011) found some positive

\footnotetext{
${ }^{1}$ According to the Central Statistics Agency of Ethiopia (CSA), the rural population is estimated to constitute about $83 \%$ of the total which is estimated at 87,952, 000 as of July 2014. http://www.csa.gov.et/ (accessed Nov 17, 2015).
} 
impact of the program on food security, asset holdings and income growth, there is little evidence of graduation. ${ }^{2}$ These studies attribute the lack of graduation, among other factors, to limited efficiency in program implementation, higher food prices and the nature of the program, i.e. targeting households, which are both poor and food insecure. Yet, what is missing in these studies (and in the broader empirical literature on the determinants of food security) is the importance of psychological factors or 'internal' constraints, such as low aspirations. However, internal constraints are also important for they could reinforce external constraints (or material deprivations) and this may lead to a self-sustaining trap of poverty and low levels of proactivity (Appadurai 2004; Ray 2006; Dalton et al. 2016). This is because poverty limits the people's 'capacity' to aspire (Appadurai 2004) by creating mental models that uniquely diminish the significance of some features of the environment while magnifying others (Bernard et al. 2008). Nonetheless, whether aspiration failure is a cause or a consequence of poverty is inconclusive. For example, Ray (2006) viewed poverty as both a result of and a cause of a failure of aspirations. Dalton et al. (2016), on the other hand, theoretically showed that while both the rich and the poor may share the same preferences and also behavioural bias in setting aspirations, poverty exacerbates the effects of this behavioural bias leading to behavioural poverty traps and the failure of aspirations, ultimately affecting their choices of effort.

Aspirations can be understood as assumed targets or reference points (Payne et al. 1980), hence they are motivators of effort. This may be reflected, for example, in terms of creating opportunities or exploiting available ones (Bandura 2009; Bernard et al. 2008), which in turn may lead to achieving better well-being outcomes such as food security. In this regard, in rural Ethiopia, Bernard et al. (2011) and Bernard and Taffesse (2012) found evidence that low aspirations are correlated with low demand for long-term loans and low use of such loans for long-term investments. Elsewhere, other studies have found strong correlations between aspirations and: expenditures on agricultural inputs, yields, and savings (Kosec et al. 2012), savings choices and health-seeking behavior (Ghosal et al. 2013), private school enrolment (Galab et al. 2013), educational outcomes (Serneels and Dercon 2014), dropout behaviour (Goux et al. 2014), career aspirations and educational attainment of adolescent girls (Beaman et al. 2012), and risky choice behaviour (Payne et al. 1981). Further, based on a randomized control, Bernard et al. (2014) showed that aspirations can be altered, implying that a potential role for policy exists. Despite the growing literature linking aspirations and effort or forward-looking behaviour in general, the effect of aspirations on food security remains

\footnotetext{
2 "Graduation" is a situation where a household can meet its food needs for all 12 months and is able to withstand modest shocks in the absence of the PSNP (GFDRE 2007).
}

largely unexplored. This study, motivated by the related literature, contributes to filling the gap in the literature by testing the hypothesis that aspirations are correlated with household food security in rural Ethiopia.

\section{Some concepts and measurements of food (in)security}

Food security is a complex concept and its definition continues to evolve. The latest definition that refined the one adopted in the 1996 World Food Summit states that "food security (is) a situation that exists when all people, at all times, have physical, social and economic access to sufficient, safe and nutritious food that meets their dietary needs and food preferences for an active and healthy life" (FAO 2002). According to Jones et al. (2013), this definition addresses concerns related to: the inequitable distribution of food not only within countries but also within households, the ability to acquire socially and culturally acceptable food and the ways in which to acquire it, and the macro- and micronutrient composition of the food. Food insecurity on the other hand is a state "when people do not have adequate physical, social or economic access to food" as defined above (FAO 2002).

The multiple approaches and tools used for assessing food security reflect the complexity of the operationalization of the concept. For example, in some cases the concept of food insecurity is used interchangeably with nutrition insecurity even though nutrition security requires food security along with "care, health and hygiene practices" (Jones et al. 2013). Undernutrition, which is "caused by undernourishment defined as a level of food intake insufficient to meet dietary energy requirements" (FAO, IFAD and WFP 2015), is also often used to measure food and nutrition security. Jones et al. (2013) and Benson (2004) showed the different overlapping concepts (see Fig. 1). They can be apprehended by various food and nutrition security measurements, their choice best dictated by a clear understanding of their underlying constructs and the identification of their intended use (Jones et al. 2013)

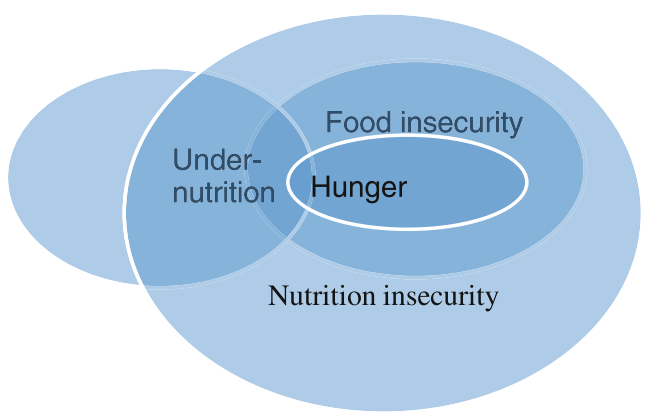

Fig. 1 Overlapping concepts within the context of food and nutrition security. The figure is from Jones et al. (2013) and Benson (2004). Used with permission from the International Food Policy Research Institute 


\section{Empirical evidence on the state of food (in)security and their determinants}

Existing studies on food security largely ignore the role of aspirations. Hence, the main hypothesis of this study is motivated by the related literature reviewed in the introduction. The literature briefly reviewed in this section is intended to guide our choice of confounding factors to be included in the analysis, in order to better isolate the relationship between aspirations and food security in rural Ethiopia.

To begin with, the latest report on the State of Food Insecurity in the World (FAO, IFAD and WFP 2015) estimates the number of people undernourished in 2014-16 at 795 million or $10.9 \%$ of the total, a reduction from $18.6 \%$ in 1990-92. The report notes that the vast majority of the hungry ( 780 million people) live in the developing world and the overall share of the hungry currently stands at $12.9 \%$ of the total population. The same report estimates that the share of people in Ethiopia who are undernourished in $2014-16$ is 32\%, a reduction from $74.8 \%$ in $1990-92$. According to the report, this improvement in Ethiopia could be attributed to several interlinked factors including the high GDP growth rate the country has been experiencing in recent years and the existing social protection program (PSNP). This assertion echoes other studies such as those of the World Bank (2016), Berhane et al. (2011, 2014) and Dorosh and Rashid (2012). According to the World Bank (2016), for example, real GDP growth in the country averaged $10.9 \%$ between 2004 and 2014 and a significant part of this growth came from agriculture. If this is indeed the case, the reduction in the number of undernourished is not surprising for the majority of the people in Ethiopia depend on agriculture, a sector which has been found to have a high growth poverty elasticity (e.g. Christiaensen and Demery 2007), and poverty is arguably one of the main determinants of food and nutrition insecurity. In this context, Tafesse (2005) estimated that a $1 \%$ increase in agricultural per capita value added in Ethiopia would result in a $1 \%$ decline in the poverty level of rural households.

Although the concept of food and nutrition security (FNS) is evolving, rigorous studies on the determinants of FNS in Ethiopia at the national level are largely lacking. A brief review of available studies, which are mainly limited to smaller geographic areas and often associated with project evaluations, sheds some light regarding one or other domains of food security. In this context, Asenso-Okyere et al. (2013), for example, studied the determinants of food security in selected agro-pastoral communities in south-eastern Ethiopia. Using availability of food in the household as proxy indicator for food security, they found that the most significant factors affecting household food security were: the educational level of the spouse and that of the household head, size of farm land, availability of household assets including livestock, peace and security. Beside household endowments such as land (Feleke et al. 2005) and proximity to food markets (Abay and Hirvonen 2016), Negatu (2004) reports that livelihood diversification strategies such as livestock rearing, growing cash crops, and engagement in trading are important factors for achieving household food security.

Food insecurity is also affected by seasonality or by irregular shocks such as weather events, deaths or conflicts (Barrett 2010). Based on a household survey data from 15 villages in rural Ethiopia, Dercon and Krishnan (2000), for example, found that the body mass index, a widely used indicator of FNS, of adults in poor households as opposed to richer households, was affected by idiosyncratic agricultural shocks. Food insecurity may be chronic or transitory, depending on the frequency of such shocks (Jones et al. 2013). In response to temporary shocks, households may resort to the sale of assets and other coping strategies which may, in turn, lead to more severe shocks, failed returns on investments, and an eventual fall into a state of chronic food insecurity (Jones et al. 2013). In the event of such shocks, food aid through different modalities is the often used policy response. In this context, a few studies have examined the importance of food aid programs following drought or harvest failures on food security in Ethiopia (e.g. Yamano et al. 2005; Quisumbing 2003; and Gilligan and Hoddinott 2007). These studies found positive impact of such transfers on consumption or child nutrition outcomes, but Gilligan and Hoddinott (2007) also uncovered some evidence of food aid dependency. In addition, even the achieved positive effects were considered to be short term as the country continued to suffer from food insecurity even in good harvest years (Clay et al. 1999). It is this realization that led to the policy shift from such "ad hoc responses" to the more planned and systematic approach of the PSNP (GFDRE 2009).

In general, the presence of widespread food insecurity in Ethiopia is argued to be the result of several factors including recurrent drought and heavy reliance on nature, use of backward agricultural technologies (or low input - low output production systems), and inappropriate agricultural policies in the past (Devereux 2000). Relatedly, von Braun and Olofinbiyi (2007) more broadly classified the major factors of food crisis in the country as: population pressure, production failures, marketing failures, and policy, institutional, and organizational failures.

\section{Methods}

\section{Data}

A household survey was conducted between January and March 2014 in Ethiopia. We re-interviewed an existing sample of agricultural households surveyed in 2006 and again in 2010 in Oromia region under an NGO project promoting 
Table 1 Aspirations level the respondent would like to achieve

\begin{tabular}{|c|c|c|c|c|c|}
\hline & \multicolumn{2}{|c|}{ Male $(N=329)$} & \multicolumn{2}{|c|}{$\operatorname{Female}(N=346)$} & \multirow{2}{*}{$\begin{array}{l}\text { diff }=\text { Mean(Males') - Mean(Females' } \\
P \text {-value }\end{array}$} \\
\hline & Mean & Std. Dev. & Mean & Std. Dev. & \\
\hline Income & 202,325 & 277,956 & 125,833 & 210,791 & 0.0001 \\
\hline Assets & 495,930 & 731,861 & 240,052 & 458,001 & 0.0000 \\
\hline Social status & 94 & 15 & 87 & 20 & 0.0000 \\
\hline Children"s education & 15 & 3 & 14 & 3 & 0.0048 \\
\hline Aggregate aspirations index $\left(A_{i}\right)$ & 0.198 & 0.606 & -0.147 & 0.571 & 0.0000 \\
\hline
\end{tabular}

Income and Wealth are measured in terms of Ethiopian Birr (The official exchange rate during the time of the survey was 1 USD $=19$ ETB), Children's Education in terms of grades/years of education; and, Social Status in terms of the percentage of people in that village that ask for the individual's advice on some important decisions

agricultural innovations, which ended in 2010. The original survey used a mix of purposive and random sampling procedures to select 390 households from three study sites (i.e. 130 households per site) (Aredo et al. 2008). The primary sampling unit (i.e. study site) consisted of three pairs of neighboring districts or woredas, namely Bakko and Sibu-Sire, Lume and Adaa, and Hettosa and Tiyyo. The districts were chosen based on the density of cultivation of the major crop (maize, teff or wheat) and on the presence of active farmers' cooperatives. In the second stage, kebeles (sub-districts) with active farmers' cooperatives were purposively selected. Finally, using the participating households within a cooperative as the sampling frame, households were randomly selected.

Our survey covered 379 households. Between one and three households in each district dropped out of our survey for various reasons, including death, relocation to another area or unavailability for the survey interview. Nevertheless, when compared against the full sample, the households that dropped out of the survey did not show any statistically significant baseline difference with regards to key indicators such as income, wealth, and landholdings (results not reported but available upon request). Further, due to a (non-systematic) problem of missing data on some indicators, the number of observations in the regression analyses (at household level) varied between 374 and 375. Also, about 10\% of households in the sample were female (single) headed, and they dropped out of some specifications that control for the characteristics of both the household head and the spouse. As a result, the number of observations for some specifications was 302 .

In addition to the basic socio-economic indicators, the survey collected information on individual aspirations and future expectations on four indicators including: income, wealth, social status and children's education. The survey also collected information about the weight each respondent attached to each of the four indicators. ${ }^{3}$ Following Beaman et al. (2012) and

\footnotetext{
3 Appendix presents a detailed description of the measurement of aspirations including the survey instrument, the theory underlying the indicators used and the construction of the aggregate index, and the data collection.
}

Bernard and Taffesse (2014), the aspirations level was calculated using an aggregate index based on respondents' answers to questions about their aspirations in the four dimensions. The aggregate aspirations index was then used to classify individuals into low-aspirations and high-aspirations status relative to the district average.

The calculation of the aggregate aspirations index $\left(A_{i}\right)$ can be represented as:

$A_{i}=\sum_{n=1}^{4}\left(\frac{a_{n}^{i}-\mu_{n}^{d}}{\sigma_{n}^{d}}\right) \cdot w_{n}^{i}$

Where:

$a_{n}^{i} \quad$ is the aspired outcome of individual $i$ on dimension $n$ (income, assets, education, or social status).

$\mu_{n}^{d} \quad$ is the average aspired outcome in district $d$ for outcome $n$.

$\sigma_{n}^{d} \quad$ is the standard deviation of aspired outcomes in district $d$ for outcome $n$.

$w_{n}^{i} \quad$ is the weight individual $i$ places on dimension $n$.

\section{Descriptive statistics}

\section{Aspirations}

Table 1 presents the level of aspirations of the respondents by gender along with the corresponding mean comparison tests. In general, males revealed higher level of aspirations in all dimensions as well as the aggregate index, and the mean differences were statistically significant. Table 2 gives the descriptive statistics on the weights respondents attached to each of the four dimensions of aspirations. In a decreasing order, the average weight respondents gave was $30 \%$ to Income, $26 \%$ to Children's Education, 24\% to Assets, and 20\% to Social Status. In some cases, Children's Education gets the maximum possible weight, which also exhibits the highest 
Table 2 Mean of relative importance (or weights) respondents attach to the four dimensions of aspirations (Out of the total score of 20), $(N=675$ )

\begin{tabular}{lllll}
\hline Variable & Mean & Std. Dev. & Min & Max \\
\hline Income & 6.00 & 2.10 & 0 & 15 \\
Assets & 4.71 & 1.43 & 0 & 10 \\
Social Status & 4.09 & 1.59 & 0 & 11 \\
Children's Education & 5.23 & 2.18 & 0 & 20 \\
\hline
\end{tabular}

dispersion in the data followed by the weight respondents attach to Income. ${ }^{4}$

\section{Food security}

Food security, as discussed before, is a broad and complex concept and we try to capture its multidimensionality (i.e. availability, access, utilization and stability) by employing widely used indicators. We constructed triangulating measures of food (in)security including per-capita calorie consumption, food consumption score (FCS), household dietary diversity score (HDDS), household food insecurity access scale (HFIAS), and the incidence of inadequate food supply in the household in the previous 12 months. We captured intra-household food allocations based on the information we collected by asking whether all household members ate the same diet, and whether each of them ate a more- or less- diversified diet and how many times a day, by age categories.

The measurement of food consumption using kilocalories (such as per-capita calorie consumption) is referred to as the "gold standard" to measure food security but its implementation is challenging for it requires the collection of detailed food intake data, which is time consuming (WFP 2008). This study, benefitted from the availability of such information in the data, which also helped triangulate the result from other indicators. One of the alternative tools for measuring food security is the WFP's (2008) FCS, which measures the frequency of consumption of different food groups consumed by a household during the 7 days before the survey. In this approach, different food items are first categorized into 9 main groups and a food consumption score is then calculated using weights assigned to each food group. ${ }^{5}$ Using FCS cut-offs which have been validated based on data collected from households in different countries (e.g. Wiesmann et al. 2009), this technique categorises

\footnotetext{
${ }^{4}$ Descriptive statistics of other variables used in the study are presented in Table 8 in the Appendix.

${ }^{5}$ The 9 main food groups and the given corresponding weights (in parentheses) include- Main staples: cereals, starchy tubers and roots (2); Pulses: legumes and nuts (3); Meat and fish: beef, goat, poultry, pork, eggs and fish (4); Vegetables (including green leaves) (1); Fruits (1); Oil: oils, fats and butter (0.5); Milk: milk, yogurt and other diary (4); and Sugar: sugar and sugar products, honey (0.5). For details including calculation steps, see WFP (2008).
}

households into three food security groups: poor, borderline and acceptable.

A related composite measure is the HDDS, which reflects the average household dietary diversity and proxies for household's food access (Swindale and Bilinsky 2006). HDDS differs from FCS as it does not attach any weight among different food items and also does not take into account the frequency of consumption of a certain food. Further, it often uses a 24-h recall period, which is shorter than the seven-day recall used in FCS. The average HDDS was calculated based on whether anyone in the household consumed any of the 12 types of food groups. ${ }^{6}$ To examine household food access, the resulting HDDS was compared among income groups such as income-terciles.

On the other hand, household food insecurity could also be measured using the HFIAS, which captures the household's food insecurity (in terms of access), including the frequency of occurrence of the event in the 4 weeks prior to the survey (Coates et al. 2007). In this measure, three dimensions of occurrence of food insecurity are captured: "anxiety and uncertainty about the household food supply; insufficient quality (includes variety and preferences of the type of food); and, insufficient food intake and its physical consequences" (Coates et al. 2007: p.6). The HFIAS is then calculated by summing over the frequency-of-occurrence of food insecurity-related conditions with higher values indicating severe food insecurity. Following the recommended cut-offs (Coates et al. 2007), households were then categorised into 4 levels of household food insecurity: food secure, mild, moderately and severely food insecure. Next, we provided empirical evidence on the level of household food (in)security among the study households using the indicators discussed above.

Based on the direct responses by the household head (and/ or the spouse), the data suggested that only about $7 \%$ of households did not have enough food in the previous 12 months. In terms of intra-household food allocations, under-five children had, on average, 4 meals per-day by comparison to 3 meals eaten by other household members. Further, about $83 \%$ of households reported that all household members ate roughly the same diet while the remaining reported that children ate more diverse foods.

Based on the recommended cut-offs of food (in)security measurements such as FCS and HFIAS, the data suggest that the share of households in the sample who were food insecure lay between 7 and $10 \%$ (see Table 3). ${ }^{7}$ However, when we

\footnotetext{
${ }^{6}$ These food groups include: cereals; root and tubers; vegetables; fruits; meat, poultry offal; eggs; fish and sea food; pulses/legumes/nuts; milk and milk products; Oil/fats; Sugar/honey; miscellaneous. HDDS is then calculated following Swindale and Bilinsky (2006).

${ }^{7}$ In this study, we merged the food insecure categories (i.e. the poor and borderline in FCS and Calorie consumption, and the mildly, moderately and severely food insecure categories for HFIAS) since the number of observations for each were too small for meaningful inference. We thank one of the reviewers for this useful suggestion.
} 
Table 3 Share of households by food (in)security profile

\begin{tabular}{lll}
\hline & Freq. & Percent \\
\hline FCS & & \\
$\quad$ Poor or borderline $(\mathrm{FCS}<=42)$ & 27 & 7.1 \\
$\quad$ Acceptable $(\mathrm{FCS}>42)$ & 351 & 92.8 \\
HFIAS & & \\
$\quad$ Food secure & 340 & 90.2 \\
$\quad$ Mildly to severely food insecure & 65 & 9.8 \\
Per-capita calorie consumption & & \\
$\quad$ Poor or borderline $(<2100$ kcal $)$ & 103 & 27.3 \\
Acceptable $(>=2100 \mathrm{kcal})$ & 275 & 72.7 \\
\hline
\end{tabular}

investigated calorie consumption using $2100 \mathrm{kcal}$ per person per day as dietary energy requirement, ${ }^{8,9}$ the share of households that can be considered food insecure increased to $27 \%$ (Table 3). These figures may seem great underestimates of the level of food insecurity by the country standard since FAO, IFAD and WFP's (2014) estimate puts the share of people undernourished in 2012-14 at 35\%. However, we offer two reasons for our results: (1) our sample households were drawn from relatively well-off districts in terms of average land holdings and agricultural potential, and (2) data were collected immediately after harvest. These two factors may tend to overemphasize the availability of food in the sample households. Nonetheless, availability of food does not necessarily guarantee access to- and utilisation of- food and by extension overall food security. To capture the household's food access, we cross-tabulated one measure of diet quality (HDDS) against per-capita food expenditure terciles. According to Fig. 2, the average diet diversity increases with the increase in expenditure. Further, consumption of food groups such as fruits, meats, and eggs vary greatly by income group with progressive increase. For example, the share of households that consume fruits, meats, and eggs for the lowest expenditure group is $13 \%, 21 \%$, and $33 \%$, respectively while corresponding figures for each food group by the middle expenditure group are roughly twice, and that by the top expenditure group are roughly thrice (Fig. 2).

Finally, we triangulated relations among the different food (in)security indicators used in this study. Pairwise correlation of per-capita calorie consumption, FCS, HDDS, HFIAS and per-capita food expenditure suggests that all except HFIAS score were statistically significantly correlated with each other

\footnotetext{
$\overline{8}$ The cut-off point, as the minimum caloric requirement, used by official reports in Ethiopia is $2200 \mathrm{kcal}$ (See MoFED 2013). If we were to use that cut off point, the number of food insecure groups would rise to $32 \%$. However, we used 2100 kcal cut-off to keep consistency with the internationally used measures and in line with other indicators employed in this study.

${ }^{9}$ The calorie value of foods consumed in the household was calculated using FAO's calorie conversion factors. Calorie/gmhttp://www.fao.org/docrep/003 /X6877E/X6877E20.htm. Calorie consumption thresholds were based on Wiesmann et al. (2009).
}

(i.e. $p<0.01$ ) (Table 4). Note, however, that since households draw their calories mainly from cereals, the correlation coefficients of FCS and HDDS with per-capita calorie consumption are relatively low (i.e. less than 0.3 ). Yet, as expected, there was a high correlation coefficient between FCS and HDDS since both indicators reflect the diversity of foods consumed. HFIAS score is also statistically significantly correlated with FCS and per-capita food expenditure (i.e. at $p<0.1$ and $p<0.05$ respectively), though the correlation is low. The latter can be explained by the different nature of the self-reported HFIAS, which may also reflect tastes, preferences and traditions.

One of the preliminary approaches to explore the possible links between household food security and aspirations is to examine the share of people with low aspirations that belong in each food (in)security profile across indicators. Table 5 presents such descriptive statistics, differentiated by the aspirations of the household head and of the spouse. ${ }^{10}$ According to Table 5, in all three food (in)security indicators, the share of household heads with low aspirations is greater in households that are considered "food insecure" than those of "food secure." With the exception of calorie consumption indicator, the same is also true for the spouses. For example, among households who are considered "food insecure" based on FCS, the share of household heads with low aspirations is $56 \%$ while the corresponding figure for spouses is $75 \%$. In terms of HFIAS, the corresponding figures for household heads and spouses are $57 \%$ and $72 \%$, respectively. These bivariate results seem to indicate that there could be some correlations between aspirations and household food security. Further, Table 5 implies that it may be useful to control for the aspirations status of both the household head and of the spouse while studying household food security correlates using multivariate analysis, which we do next.

\section{Estimation and results}

The food security status $(y)$ of the $\mathrm{j}^{\text {th }}$ household can be expressed in the following function:

$y_{j}=f(A, I, H, C)$

Where $A$ represents the aspirations status (of the household head and of the spouse), $I$ denotes other characteristics of the household head and of the spouse, $H$ and $C$ respectively denote other household and community level characteristics. As opposed to the assumption behind unitary household models where preferences (or decision making) of the household is often proxied by the preferences of the head of the household, in this study we assumed joint decision making by the two

\footnotetext{
${ }^{10}$ We focus on FCS, HFIAS and per capita calorie consumption because (a) Per-capita food expenditure is not used as a FS measure in this study but as an indirect measure of food access and (b) the HDDS does not have standard cutoffs and is best used in relation to other indicators.
} 
Fig. 2 Share of households consuming specific food groups by per-capita consumption expenditure terciles

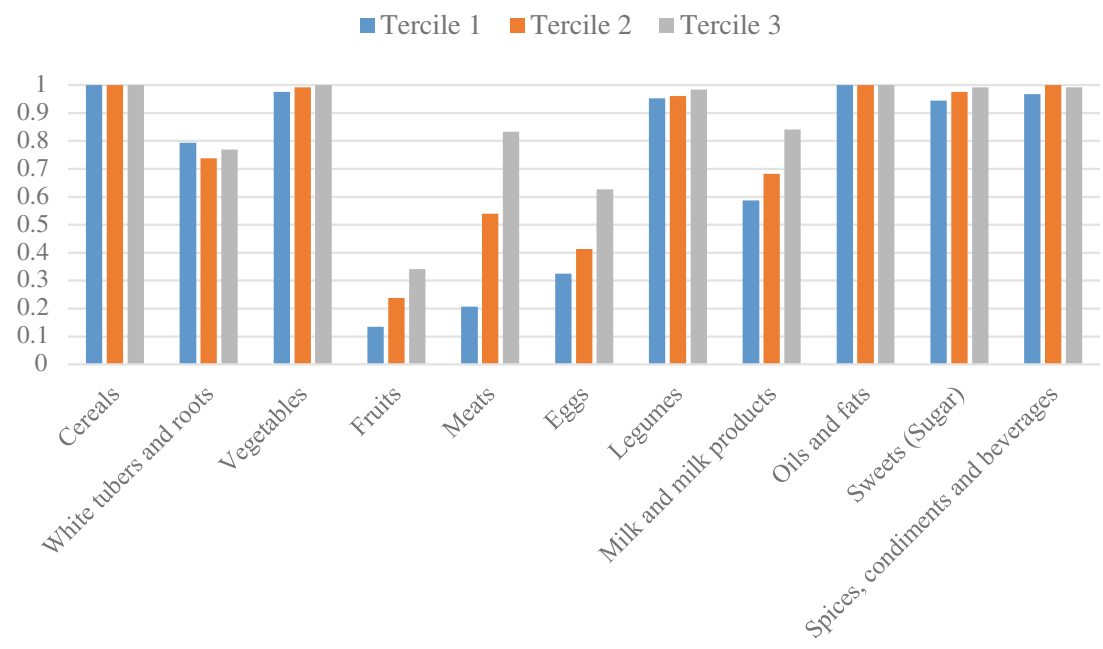

spouses and hence the food security of the household was determined by the characteristics of both the head of the household and of the spouse, in combination with other household and community characteristics including district fixed effects. We estimated a series of an ordinary least squares (OLS) models relating indicators of household food (in)security with aspirations of the household head and of the spouse, and a wide range of other potential determinants which were selected based on their importance in the food security literature reviewed in this study. Yet, our purpose remained to see if aspirations of the two spouses, given other factors, were strong correlates of household food security without necessarily claiming causal relations. This is because results might still be confounded by unobserved householdspecific heterogeneity, which we could not account for since we only have cross-sectional observations on the main variables of interest (i.e. aspirations and food security). Further, aspirations are formed based on own outcomes in the past as well as present (Ray 2006) and they tend to change in the light of new experiences (including shocks), choices and information (Leavy and Smith 2010). We attempted to control for such dynamics using indicators for experience of shocks, change of income over time, and present level income and wealth indicators since they may also have a bearing on food security. In addition, since the same level of shocks may be perceived differently by different people, depending on their wealth status and demographic characteristics, controlling for such factors would help to tease out the correlations between the two main variables of interest better (i.e. food security and aspirations). Two-way or reverse causation (i.e. higher food security may lead to higher aspirations) is also another concern in the study of a causal link, which cannot be tackled with crosssectional data. Nonetheless, it is believed that if properly executed an exploratory study such as this one is in itself a strong contribution. Angrist and Pischke (2009) even argue that "correlation can sometimes provide pretty good evidence of a causal relation" (p.113).

\section{Results and discussion}

We have shown in a bivariate context that aspirations and food security are positively correlated. In this section, we examine if that relationship still holds and whether the correlation is statistically significant after controlling for other potential determinants of the four pillars of household food security, namely, availability, access, utilization, and stability of food. Following the existing literature and data availability, we used per-capita calorie consumption, FCS, HDDS and HFIAS as measures of food (in)security.

Table 4 Pairwise correlation of various food (in)security indicators

\begin{tabular}{|c|c|c|c|c|c|}
\hline & $\begin{array}{l}\text { Per-capita calorie consumption } \\
\text { per day }\end{array}$ & FCS & HDDS & HFIAS score & $\begin{array}{l}\text { Per-capita monthly } \\
\text { food expenditure }\end{array}$ \\
\hline Per-capita calorie consumption per day & 1 & & & & \\
\hline FCS & $0.2658 * * *$ & 1 & & & \\
\hline HDDS & $0.2305 * * *$ & $0.7294 * * *$ & 1 & & \\
\hline HFIAS score & -0.104 & $-0.1356^{*}$ & -0.1295 & 1 & \\
\hline Per-capita monthly food expenditure & $0.7618 * * *$ & $0.4392 * * *$ & $0.3903 * * *$ & $-0.1634 * *$ & 1 \\
\hline
\end{tabular}

$* p<0.10, * * p<0.05, * * * p<0.01$ 
Table 5 Percentage of households with low-aspirations by food (in)security profile

\begin{tabular}{lll}
\hline & Head & Spouse $^{\mathrm{a}}$ \\
\hline FCS & & \\
$\quad$ Poor or borderline $(\mathrm{FCS}<=42)$ & 55.6 & 75 \\
$\quad$ Acceptable (FCS $>42)$ & 30.8 & 64.0 \\
HFIAS & 56.7 & 72.4 \\
$\quad$ Mildly to severely food insecure & 30 & 64.0 \\
$\quad$ Food secure & & \\
Per-capita calorie consumption & 37.8 & 61.9 \\
$\quad$ Poor or borderline $(<2100 \mathrm{kcal})$ & 30.6 & 65.6 \\
$\quad$ Acceptable $(>=2100 \mathrm{kcal})$ &
\end{tabular}

${ }^{\text {a }}$ Corresponding statistics do not include female headed households which account for about $10 \%$ of the total

Tables 6 presents a summary of the main correlates of food (in)security, based on a unitary household model framework. Results suggest that aspirations are indeed strongly associated with household food (in)security in three out of the four indicators (i.e. per-capita calorie consumption, HDDS and HFIAS). For example, according to Column 1, a standard deviation increase in the aspirations level of the household head is associated with a $(323 \times 0.61)=197$ cal per-capita per-day increase in household consumption. ${ }^{11}$ This is roughly an increase of a $(197 / 3035)=6.5 \%$ over the mean calories consumption per capita per day. Also, the coefficient estimate further increases when we control for income and indicators of various shocks experience (Column 2). Similarly, according to Columns 5 and 7 respectively, a standard deviation increase in the aspirations index of the household head was associated with a $(0.21 \times 0.61)=0.13$ points increase in HDDS, and a $(-0.30 \times 0.61)=0.18$ points decrease in HFIAS (recall that unlike other indicators, HFIAS actually measures food insecurity). ${ }^{12}$ In reference to the corresponding mean outcomes, these are roughly a $(0.13 / 8.68)=1.5 \%$ increase in HDDS, and a $(0.18 / 0.48)=38 \%$ decrease in HFIAS.

Next we tested if the aspirations and other characteristics of the spouse of the household head were also important correlates of household food security, given the aspirations and other characteristic of the household head and other controls (see Table 7). It is assumed that the head of the household and the spouse often talk to each other and exchange information.

\footnotetext{
$\overline{11}$ The mean and standard deviation of the aspirations index of the household head are 0.158 and 0.61 , respectively.

12 The mean values, corresponding to Table 6, of the per-capita calorie consumption, FCS, HDDS, and HFIAS are 3035, 71, 8.6, and 0.5, respectively. Yet, in specifications where the characteristics of both the household head and the spouse are considered (i.e. Table 7), female headed households drop out from the analysis. In that case, the corresponding mean values of the household per-capita calorie consumption, FCS, HDDS, and HFIAS are respectively 2997, 71.4, 8.68, and 0.48 .
}

This may lead the two spouses to individually update their aspirations (Ray 2006; Leavy and Smith 2010) and this in turn may influence their decision-making in the household. Thus, we controlled for such feedback (or interactions) effect using the interaction term of the aspirations of the two spouses. According to Table 7, the aspirations index of the spouse is negatively associated with the household per capita calorie consumption, at $10 \%$ level of statistical significance (Columns 1 and 2). While the negative relationship may seem surprising, it may also indicate the existence of trade-offs between current consumption and savings (or forward-looking) behaviour. That is, with the increase in aspirations, the spouse of the household head may tend to cut back on current consumption and save for future investment or consumption smoothening. Similarly, we found that the interaction term of the aspirations of the household head and the spouse was negatively and statistically significantly correlated with FCS (Column 4). In this specification, we reject the null hypothesis of the joint test of significance of a) the aspirations of the spouse and the interaction term, ${ }^{13}$ and of b) the aspirations of the head and the spouse and their interaction term ${ }^{14}$ (Column 4). ${ }^{15}$ These results may suggest that the aspirations of the two members of the same households have different effects on household food security.

The strong and positive correlations between aspirations of the household head and food security indicators should be put into context, as explained next. As motivators, aspirations may affect food security through different channels. First, aspirations may improve households' forward looking behavior (Bernard et al. 2014) and this may involve reducing risk by diversifying livelihood strategies (e.g. by engaging in nonfarm income generating activities) which may lead to improved food security (e.g. through improved purchasing power or economic access). Secondly, aspirations may motivate households to reduce their risk aversion (Payne et al. 1981) and this may lead to investment in agricultural innovations (e.g. Mekonnen and Gerber 2016), major determinants of agricultural productivity, which in turn may determine some aspects of food security (such as food availability and stability). Thirdly, farming in Ethiopia is a labor intensive sector and productivity may depend on the physical fitness of farm labor, which in turn is determined by the health status and consumption of foods that provide the necessary nutrients and adequate calories (Asenso-Okyere et al. 2011). In this context, aspirations may motivate households to consume more diversified and dietary foods and make other investments that would improve their health and nutrition status, linked to at least one aspect of food security (e.g. utilisation). In contrast, aspirations may also enhance savings behaviour.

\footnotetext{
${ }^{13}$ With an $\mathrm{F}(2,269)=6.93$ and Prob $>\mathrm{F}=0.0012$.

${ }^{14}$ With an $F(3,269)=4.63$ and Prob $>F=0.0036$.

${ }^{15}$ Similarly, with $F(3,269)=4.53$ and Prob $>F=0.0041$, we reject the null hypothesis of the joint test of significance of the aspirations of the head and of the spouse and their interaction term of the specification in Column 2.
} 
Table 6 Correlation of aspirations of the household head and other factors with household food (in)security

\begin{tabular}{|c|c|c|c|c|c|c|c|c|}
\hline VARIABLES & $\begin{array}{l}\text { (1) } \\
\text { per-capita calorie }\end{array}$ & $\begin{array}{l}\text { (2) } \\
\text { per-capita calorie }\end{array}$ & $\begin{array}{l}(3) \\
\text { FCS }\end{array}$ & $\begin{array}{l}\text { (4) } \\
\text { FCS }\end{array}$ & $\begin{array}{l}(5) \\
\text { HDDS }\end{array}$ & $\begin{array}{l}(6) \\
\text { HDDS }\end{array}$ & $\begin{array}{l}(7) \\
\text { HFIAS }\end{array}$ & $\begin{array}{l}(8) \\
\text { HFIAS }\end{array}$ \\
\hline Aspirations Head & $\begin{array}{l}322.47 * * * \\
(113.89)\end{array}$ & $\begin{array}{l}359.56^{* * *} \\
(116.35)\end{array}$ & $\begin{array}{l}2.52 \\
(1.68)\end{array}$ & $\begin{array}{l}2.24 \\
(1.68)\end{array}$ & $\begin{array}{l}0.21 * \\
(0.12)\end{array}$ & $\begin{array}{l}0.21 * \\
(0.12)\end{array}$ & $\begin{array}{l}-0.30 * * \\
(0.13)\end{array}$ & $\begin{array}{l}-0.29 * * \\
(0.13)\end{array}$ \\
\hline Female hh head $^{\mathrm{a}}$ & $\begin{array}{l}154.07 \\
(254.60)\end{array}$ & $\begin{array}{l}31.61 \\
(254.17)\end{array}$ & $\begin{array}{l}-5.26 \\
(3.37)\end{array}$ & $\begin{array}{l}-5.36 \\
(3.35)\end{array}$ & $\begin{array}{l}-0.49^{* *} \\
(0.25)\end{array}$ & $\begin{array}{l}-0.54 * * \\
(0.24)\end{array}$ & $\begin{array}{l}0.11 \\
(0.34)\end{array}$ & $\begin{array}{l}0.07 \\
(0.33)\end{array}$ \\
\hline \multicolumn{9}{|l|}{ Age (ref. < 31) } \\
\hline HH head Age $31-50^{\mathrm{a}}$ & $\begin{array}{l}93.82 \\
(235.80)\end{array}$ & $\begin{array}{l}84.96 \\
(249.93)\end{array}$ & $\begin{array}{l}-1.62 \\
(4.04)\end{array}$ & $\begin{array}{l}-1.08 \\
(4.13)\end{array}$ & $\begin{array}{l}-0.32 \\
(0.30)\end{array}$ & $\begin{array}{l}-0.28 \\
(0.30)\end{array}$ & $\begin{array}{l}-0.24 \\
(0.59)\end{array}$ & $\begin{array}{l}-0.23 \\
(0.58)\end{array}$ \\
\hline HH head Age above $51^{\mathrm{a}}$ & $\begin{array}{l}-38.44 \\
(255.01)\end{array}$ & $\begin{array}{l}-46.67 \\
(262.45)\end{array}$ & $\begin{array}{l}-2.86 \\
(4.18)\end{array}$ & $\begin{array}{l}-2.43 \\
(4.23)\end{array}$ & $\begin{array}{l}-0.53 * \\
(0.32)\end{array}$ & $\begin{array}{l}-0.49 \\
(0.32)\end{array}$ & $\begin{array}{l}-0.50 \\
(0.55)\end{array}$ & $\begin{array}{l}-0.47 \\
(0.53)\end{array}$ \\
\hline \multicolumn{9}{|l|}{ Education (ref. no education) } \\
\hline Head education: $1-4^{\mathrm{a}}$ & $\begin{array}{l}153.25 \\
(188.04)\end{array}$ & $\begin{array}{l}101.21 \\
(192.26)\end{array}$ & $\begin{array}{l}-4.18 \\
(2.63)\end{array}$ & $\begin{array}{l}-5.07 * \\
(2.70)\end{array}$ & $\begin{array}{l}-0.40^{* *} \\
(0.20)\end{array}$ & $\begin{array}{l}-0.46^{* *} \\
(0.20)\end{array}$ & $\begin{array}{l}0.14 \\
(0.35)\end{array}$ & $\begin{array}{l}0.11 \\
(0.34)\end{array}$ \\
\hline Head education: $5-8^{\text {a }}$ & $\begin{array}{l}93.35 \\
(178.92)\end{array}$ & $\begin{array}{l}46.01 \\
(180.12)\end{array}$ & $\begin{array}{l}0.48 \\
(2.45)\end{array}$ & $\begin{array}{l}-0.06 \\
(2.46)\end{array}$ & $\begin{array}{l}-0.07 \\
(0.19)\end{array}$ & $\begin{array}{l}-0.14 \\
(0.19)\end{array}$ & $\begin{array}{l}-0.31 \\
(0.31)\end{array}$ & $\begin{array}{l}-0.32 \\
(0.28)\end{array}$ \\
\hline Head education: $8+{ }^{a}$ & $\begin{array}{l}23.64 \\
(243.81)\end{array}$ & $\begin{array}{l}-6.43 \\
(253.20)\end{array}$ & $\begin{array}{l}0.87 \\
(2.84)\end{array}$ & $\begin{array}{l}0.37 \\
(2.86)\end{array}$ & $\begin{array}{l}-0.15 \\
(0.20)\end{array}$ & $\begin{array}{l}-0.25 \\
(0.21)\end{array}$ & $\begin{array}{l}-0.17 \\
(0.38)\end{array}$ & $\begin{array}{l}-0.14 \\
(0.37)\end{array}$ \\
\hline $\mathrm{HH}$ size(ln) & $\begin{array}{l}-1458 * * * \\
(234.34)\end{array}$ & $\begin{array}{l}-1394 * * * \\
(261.07)\end{array}$ & $\begin{array}{l}3.33 \\
(2.70)\end{array}$ & $\begin{array}{l}6.25 * * \\
(2.70)\end{array}$ & $\begin{array}{l}0.51 * * \\
(0.22)\end{array}$ & $\begin{array}{l}0.73 * * * \\
(0.22)\end{array}$ & $\begin{array}{l}0.40 \\
(0.31)\end{array}$ & $\begin{array}{l}0.42 \\
(0.35)\end{array}$ \\
\hline Dependency ratio & $\begin{array}{l}-264.17 \\
(359.46)\end{array}$ & $\begin{array}{l}-209.45 \\
(360.59)\end{array}$ & $\begin{array}{l}2.73 \\
(4.46)\end{array}$ & $\begin{array}{l}2.84 \\
(4.41)\end{array}$ & $\begin{array}{l}0.14 \\
(0.36)\end{array}$ & $\begin{array}{l}0.10 \\
(0.35)\end{array}$ & $\begin{array}{l}0.05 \\
(0.34)\end{array}$ & $\begin{array}{l}0.10 \\
(0.38)\end{array}$ \\
\hline Off-farm income ${ }^{a}$ & $\begin{array}{l}-142.02 \\
(134.62)\end{array}$ & $\begin{array}{l}-134.95 \\
(140.68)\end{array}$ & $\begin{array}{l}0.51 \\
(1.79)\end{array}$ & $\begin{array}{l}-0.33 \\
(1.86)\end{array}$ & $\begin{array}{l}0.07 \\
(0.13)\end{array}$ & $\begin{array}{l}0.03 \\
(0.14)\end{array}$ & $\begin{array}{l}0.25 \\
(0.20)\end{array}$ & $\begin{array}{l}0.19 \\
(0.20)\end{array}$ \\
\hline Value of assets $(\ln )$ & $\begin{array}{l}-44.01 \\
(63.89)\end{array}$ & $\begin{array}{l}-44.51 \\
(65.84)\end{array}$ & $\begin{array}{l}0.83 \\
(0.85)\end{array}$ & $\begin{array}{l}0.70 \\
(0.87)\end{array}$ & $\begin{array}{l}0.22 * * * \\
(0.07)\end{array}$ & $\begin{array}{l}0.19 * * * \\
(0.07)\end{array}$ & $\begin{array}{l}-0.20^{*} \\
(0.12)\end{array}$ & $\begin{array}{l}-0.19 \\
(0.12)\end{array}$ \\
\hline Livestock holding(TLU) & $\begin{array}{l}50.65 * * * \\
(17.09)\end{array}$ & $\begin{array}{l}46.50 * * * \\
(16.39)\end{array}$ & $\begin{array}{l}0.45 * * \\
(0.22)\end{array}$ & $\begin{array}{l}0.27 \\
(0.22)\end{array}$ & $\begin{array}{l}0.01 \\
(0.02)\end{array}$ & $\begin{array}{l}-0.00 \\
(0.02)\end{array}$ & $\begin{array}{l}0.01 \\
(0.02)\end{array}$ & $\begin{array}{l}0.01 \\
(0.02)\end{array}$ \\
\hline Land in ha(ln) & $\begin{array}{l}296.60 * * \\
(147.66)\end{array}$ & $\begin{array}{l}227.40 \\
(169.83)\end{array}$ & $\begin{array}{l}4.70 * * \\
(2.04)\end{array}$ & $\begin{array}{l}3.02 \\
(1.98)\end{array}$ & $\begin{array}{l}0.14 \\
(0.16)\end{array}$ & $\begin{array}{l}0.01 \\
(0.17)\end{array}$ & $\begin{array}{l}-0.25 \\
(0.19)\end{array}$ & $\begin{array}{l}-0.34 * \\
(0.20)\end{array}$ \\
\hline \multicolumn{9}{|l|}{ Average walking distance to: } \\
\hline Road (minutes)(ln) & $\begin{array}{l}-40.36 \\
(37.19)\end{array}$ & $\begin{array}{l}-38.12 \\
(37.08)\end{array}$ & $\begin{array}{l}0.54 \\
(0.45)\end{array}$ & $\begin{array}{l}0.46 \\
(0.44)\end{array}$ & $\begin{array}{l}0.02 \\
(0.03)\end{array}$ & $\begin{array}{l}0.02 \\
(0.03)\end{array}$ & $\begin{array}{l}0.02 \\
(0.03)\end{array}$ & $\begin{array}{l}0.03 \\
(0.04)\end{array}$ \\
\hline Market(minutes)(ln) & $\begin{array}{l}-17.32 \\
(75.42)\end{array}$ & $\begin{array}{l}-32.82 \\
(77.73)\end{array}$ & $\begin{array}{l}-1.54 \\
(0.94)\end{array}$ & $\begin{array}{l}-1.62 * \\
(0.93)\end{array}$ & $\begin{array}{l}-0.20 * * * \\
(0.07)\end{array}$ & $\begin{array}{l}-0.22 * * * \\
(0.07)\end{array}$ & $\begin{array}{l}-0.11 \\
(0.09)\end{array}$ & $\begin{array}{l}-0.10 \\
(0.09)\end{array}$ \\
\hline \multicolumn{9}{|c|}{ District dummy (ref. Adda-Lume) } \\
\hline Bako-Sire $^{a}$ & $\begin{array}{l}-210.51 \\
(152.87)\end{array}$ & $\begin{array}{l}-327.16^{* *} \\
(155.57)\end{array}$ & $\begin{array}{l}-0.30 \\
(2.39)\end{array}$ & $\begin{array}{l}-1.56 \\
(2.38)\end{array}$ & $\begin{array}{l}-0.33 * \\
(0.18)\end{array}$ & $\begin{array}{l}-0.40 * * \\
(0.18)\end{array}$ & $\begin{array}{l}0.57 * * \\
(0.28)\end{array}$ & $\begin{array}{l}0.41 \\
(0.27)\end{array}$ \\
\hline Hitossa-Tiyo $^{\text {a }}$ & $\begin{array}{l}833.11 * * * \\
(179.50)\end{array}$ & $\begin{array}{l}827.52 * * * \\
(193.35)\end{array}$ & $\begin{array}{l}9.39 * * * \\
(2.34)\end{array}$ & $\begin{array}{l}8.11 * * * \\
(2.44)\end{array}$ & $\begin{array}{l}0.38^{* * *} \\
(0.18)\end{array}$ & $\begin{array}{l}0.27 \\
(0.19)\end{array}$ & $\begin{array}{l}-0.16 \\
(0.16)\end{array}$ & $\begin{array}{l}-0.17 \\
(0.18)\end{array}$ \\
\hline Annual income per $\mathrm{AE}^{\mathrm{b}}$ & & $\begin{array}{l}0.02 \\
(0.04)\end{array}$ & & $\begin{array}{l}0.00 * * * \\
(0.00)\end{array}$ & & $\begin{array}{l}0.00 * * * \\
(0.00)\end{array}$ & & $\begin{array}{l}0.00 \\
(0.00)\end{array}$ \\
\hline Change in Inc. (2006-10) & & $\begin{array}{l}0.00 \\
(0.04)\end{array}$ & & $\begin{array}{l}0.00 \\
(0.00)\end{array}$ & & $\begin{array}{l}0.00 \\
(0.00)\end{array}$ & & $\begin{array}{l}-0.00 \\
(0.00)\end{array}$ \\
\hline \multicolumn{9}{|l|}{ Shocks experience $(1 / 0)$} \\
\hline Too much rain or flood ${ }^{\mathrm{a}}$ & & $\begin{array}{l}524.03 * \\
(273.78)\end{array}$ & & $\begin{array}{l}6.50 * * \\
(2.85)\end{array}$ & & $\begin{array}{l}0.53 * * * \\
(0.20)\end{array}$ & & $\begin{array}{l}0.06 \\
(0.67)\end{array}$ \\
\hline Livestock diseases $^{\mathrm{a}}$ & & $\begin{array}{l}412.95 \\
(282.34)\end{array}$ & & $\begin{array}{l}-2.27 \\
(2.86)\end{array}$ & & $\begin{array}{l}-0.15 \\
(0.21)\end{array}$ & & $\begin{array}{l}0.46 \\
(0.57)\end{array}$ \\
\hline Increased input prices ${ }^{\mathrm{a}}$ & & 91.63 & & -2.94 & & -0.07 & & 0.71 \\
\hline
\end{tabular}


Table 6 (continued)

\begin{tabular}{|c|c|c|c|c|c|c|c|c|}
\hline VARIABLES & $\begin{array}{l}\text { (1) } \\
\text { per-capita calorie }\end{array}$ & $\begin{array}{l}\text { (2) } \\
\text { per-capita calorie }\end{array}$ & $\begin{array}{l}\text { (3) } \\
\text { FCS }\end{array}$ & $\begin{array}{l}\text { (4) } \\
\text { FCS }\end{array}$ & $\begin{array}{l}\text { (5) } \\
\text { HDDS }\end{array}$ & $\begin{array}{l}\text { (6) } \\
\text { HDDS }\end{array}$ & $\begin{array}{l}(7) \\
\text { HFIAS }\end{array}$ & $\begin{array}{l}(8) \\
\text { HFIAS }\end{array}$ \\
\hline & & (206.98) & & $(3.00)$ & & $(0.19)$ & & $(0.51)$ \\
\hline \multirow[t]{2}{*}{ Death or loss of livestock ${ }^{\mathrm{a}}$} & & -112.64 & & 0.49 & & 0.27 & & -0.33 \\
\hline & & $(193.71)$ & & $(3.11)$ & & $(0.19)$ & & $(0.52)$ \\
\hline \multirow[t]{2}{*}{ Illness of head/spouse ${ }^{a}$} & & -135.50 & & 0.41 & & -0.31 & & 0.40 \\
\hline & & (205.06) & & $(2.87)$ & & $(0.23)$ & & $(0.61)$ \\
\hline \multirow[t]{2}{*}{ Illness of other family ${ }^{a}$} & & 314.70 & & $5.08 *$ & & $0.36^{*}$ & & 0.38 \\
\hline & & $(208.61)$ & & $(2.94)$ & & $(0.20)$ & & $(0.58)$ \\
\hline \multirow[t]{2}{*}{ Constant } & $5383.0 * * *$ & $5297 * * *$ & $52.44 * * *$ & $48.27 * * *$ & $6.68 * * *$ & $6.60 * * *$ & $2.18^{*}$ & 1.90 \\
\hline & $(782.53)$ & $(834.53)$ & $(10.18)$ & $(10.24)$ & $(0.75)$ & $(0.76)$ & $(1.25)$ & $(1.18)$ \\
\hline Observations & 375 & 374 & 375 & 374 & 375 & 374 & 376 & 375 \\
\hline R-squared & 0.29 & 0.31 & 0.24 & 0.28 & 0.26 & 0.30 & 0.12 & 0.15 \\
\hline
\end{tabular}

Robust standard errors in parentheses $* * * p<0.01, * * p<0.05$, * $p<0.1$

${ }^{\text {a }}$ Binary $(1 / 0)$

${ }^{\mathrm{b}} \mathrm{AE}=$ adult equivalent

When that happens, household savings may come at the expense of current consumption and hence the food security of the household may decrease, as the negative coefficient of the aspirations of the spouse (Columns 1 and 2) and the interaction term (Column 4) in Table 7 seem to suggest. Yet it is important to note that despite the wide range of control variables including wealth indicators, present income as well as income growth in the past (i.e. between 2006 and 2010), this study does not establish causal inference.

Beyond aspirations, and following the literature, other results of Table 6 focus on relevant 'external' constraints. We find that resource endowments such as household assets, land and livestock holdings are positively correlated with some of the food security indicators. This is because wealth avails

Table 7 Correlation of aspirations of the household head and that of the spouse and household food (in)security

\begin{tabular}{|c|c|c|c|c|c|c|c|c|}
\hline VARIABLES & $\begin{array}{l}\text { (1) } \\
\text { per-capita calorie }\end{array}$ & $\begin{array}{l}\text { (2) } \\
\text { per-capita calorie }\end{array}$ & $\begin{array}{l}\text { (3) } \\
\text { FCS }\end{array}$ & $\begin{array}{l}(4) \\
\text { FCS }\end{array}$ & $\begin{array}{l}(5) \\
\text { HDDS }\end{array}$ & $\begin{array}{l}(6) \\
\text { HDDS }\end{array}$ & $\begin{array}{l}(7) \\
\text { HFIAS }\end{array}$ & $\begin{array}{l}(8) \\
\text { HFIAS }\end{array}$ \\
\hline Aspirations Head & $\begin{array}{l}405.17 * * * \\
(116.72)\end{array}$ & $\begin{array}{l}425.02 * * * \\
(118.77)\end{array}$ & $\begin{array}{l}3.58^{*} \\
(1.87)\end{array}$ & $\begin{array}{l}3.58 * * \\
(1.80)\end{array}$ & $\begin{array}{l}0.27 * * \\
(0.14)\end{array}$ & $\begin{array}{l}0.28 * * \\
(0.13)\end{array}$ & $\begin{array}{l}-0.33^{* *} \\
(0.15)\end{array}$ & $\begin{array}{l}-0.31 * * \\
(0.14)\end{array}$ \\
\hline Aspirations Spouse & $\begin{array}{l}-199.36^{*} \\
(105.88)\end{array}$ & $\begin{array}{l}-211.20 * \\
(123.24)\end{array}$ & $\begin{array}{l}-2.43 \\
(1.64)\end{array}$ & $\begin{array}{l}-1.37 \\
(1.80)\end{array}$ & $\begin{array}{l}-0.08 \\
(0.11)\end{array}$ & $\begin{array}{l}-0.09 \\
(0.12)\end{array}$ & $\begin{array}{l}-0.05 \\
(0.27)\end{array}$ & $\begin{array}{l}0.01 \\
(0.30)\end{array}$ \\
\hline Aspirations of (Head×Spouse $)$ & & $\begin{array}{l}-69.38 \\
(87.94)\end{array}$ & & $\begin{array}{l}-4.50 * * * \\
(1.64)\end{array}$ & & $\begin{array}{l}-0.10 \\
(0.13)\end{array}$ & & $\begin{array}{l}0.16 \\
(0.18)\end{array}$ \\
\hline Spouse's characteristics ${ }^{\mathrm{a}}$ & Yes & Yes & Yes & Yes & Yes & Yes & Yes & Yes \\
\hline Annual income per $\mathrm{AE}^{\mathrm{b}}$ & No & Yes & No & Yes & No & Yes & No & Yes \\
\hline Change in Inc. (2006-10) & No & Yes & No & Yes & No & Yes & No & Yes \\
\hline Dummies for shocks experience $(1 / 0)$ & No & Yes & No & Yes & No & Yes & No & Yes \\
\hline Other controls ${ }^{\mathrm{c}}$ & Yes & Yes & Yes & Yes & Yes & Yes & Yes & Yes \\
\hline Constant & $\begin{array}{l}5,0583 * * * \\
(803.63)\end{array}$ & $\begin{array}{l}4912.15 * * * \\
(848.92)\end{array}$ & $\begin{array}{l}54.44 * * * \\
(12.17)\end{array}$ & $\begin{array}{l}55.43 * * * \\
(12.20)\end{array}$ & $\begin{array}{l}6.84 * * * \\
(0.88)\end{array}$ & $\begin{array}{l}6.85 * * * \\
(0.92)\end{array}$ & $\begin{array}{l}2.14 \\
(1.50)\end{array}$ & $\begin{array}{l}1.67 \\
(1.47)\end{array}$ \\
\hline Observations & 302 & 302 & 302 & 302 & 302 & 302 & 302 & 302 \\
\hline R-squared & 0.30 & 0.33 & 0.23 & 0.28 & 0.26 & 0.30 & 0.15 & 0.22 \\
\hline
\end{tabular}

Robust standard errors in parentheses $* * * p<0.01, * * p<0.05, * p<0.1$

${ }^{a}$ The Spouse's other characteristics include age and education categories similar to that of the household head listed in Table 6, and a dummy for Spouse's participation in business or wage labor. Of these, only the dummy for "Spouse education: 8+" is statistically significant (Columns 3-6)

${ }^{\mathrm{b}} \mathrm{AE}=$ adult equivalent

${ }^{\mathrm{c}}$ Other controls include those listed in Table 6 
some form of coping mechanism to the household in the event of abrupt changes that threaten their food security. Remoteness of the household from the market and asphalt road is also negatively associated with food security (Columns 4, $5 \& 6$ ), which is consistent with the findings of other studies such as that of Abay and Hirvonen (2016) who report that proximity to food markets improves consumption of more diverse diets and better child nutrition outcomes in northern Ethiopia. This is because access to roads and markets determine accessibility and stability of food. Results also suggest that female headed households are more likely to be food insecure (Columns $5 \& 6$ ). Further, results suggest that having 1-to-4 years of education (by comparison to no education) by the household head (Columns 4-6) is negatively correlated with dietary diversity of the household. This may be attributed to measurement error. Otherwise, the result is surprising since it is likely that individuals with some level of education may have better knowledge of the benefit of dietary diversity (e.g. see Strauss and Thomas (1995) for a survey of the literature). The incidence of illness of a household member other than the head and spouse (columns 4 and 6) are positively correlated with FCS and HDDS. One potential explanation is that ill people are fed with a more diverse set of foods in order to speed up recovery. ${ }^{16}$ Lastly, most of these results hold when we further include the characteristics of the spouse of the household head (Table 7, results not reported). If anything, we find that by comparison to no education, having education level higher than 8th grade by the spouse of the household head is associated with improved household food security (i.e. FCS and HDDS, results not reported but available on request). This is in line with expectations as education enhances the nutrition knowledge of the main care giver (often wives in rural Ethiopia).

\section{Summary and conclusions}

This study empirically examines whether aspirations are important correlates of food security in rural Ethiopia. We established robust evidence by employing several objective as well as subjective measures of food (in)security that also reflect the multi-dimensionality of the concept. Descriptive statistics suggest that, by comparison, the proportion of people with low-aspirations is higher among food insecure households than that of food secure, and this is true for most of the indicators.

We used regressions to relate each food (in)security outcome against the aspirations indicator and other potential drivers including human capital and the household's access to: natural capital, physical capital, financial capital, roads,

\footnotetext{
${ }^{16}$ We thank the anonymous reviewer for suggesting this as one of the possible explanations.
}

markets; and the household's experience of various shocks. To account for the unobserved factors common to all residents in each study site, we controlled for district fixed effects. The main finding of the study, which is robust across outcome indicators, is that the aspirations of the household head are strongly associated with household food security in rural Ethiopia. In contrast, we find that the aspirations of the spouse are negatively associated with some indicators of household food security. This perhaps suggests the existence of trade-offs between current consumption and savings behaviour which may compromise the current level of household food security.

Despite the cross-sectional nature of the data used in this study, which is the major limitation for unobserved household characteristics, these might affect both aspirations and food security or present the possibility of reverse causation. The robustness of findings across various indicators and specifications, however, suggest that aspirations of the household head are indeed strong correlates of household food security. Yet, it is important to note that we have controlled for present income and assets, the change in income in the past (i.e. between 2006 and 2010), and a wide range of other factors, which might affect both variables of interest (i.e. aspirations and household food security). This perhaps might help minimise the influence of the error term that would result from the unobserved heterogeneities. Nonetheless, the study also has other limitations. The survey, which this study mainly relies upon, covered an existing sample of farm households which had been interviewed by other organizations in the past. The original survey used a mix of purposive and random sampling procedures from study sites, which have high agricultural potential. This might limit the external validity of the study. Given those caveats, however, most of the findings of this study are in line with theory and some other empirical studies. Further research on the linkages between aspirations and food security could have strong policy implications if they could establish the direction of the linkage and the potential channels. To that end, data on aspirations and their determinants, as well as on food security and its determinants, cutting across time and households would be necessary.

Acknowledgements The research leading to these results received funding from the European Union's Seventh Framework Programme FP7/2007-2011 under Grant Agreement n ${ }^{\circ}$ 290,693 FOODSECURE. The authors are very thankful to Joachim von Braun and Alemayehu Seyoum Taffesse for valuable comments and support during the research work. Finally, we thank the anonymous reviewers who helped improve the text substantially. Any remaining mistakes and inconsistencies are entirely the responsibility of the authors.

\section{Compliance with ethical standards}

Conflict of interest The authors declare that they have no conflict of interest. 


\section{Appendix: measuring aspirations}

Individuals may set different goals in life, which makes aspirations multidimensional. Aspirations are also dynamic in that they tend to change in the light of new experiences, choices and information (Leavy and Smith 2010). Further, since aspirations are attitudinal in nature, measurement errors could easily arise due to "anchoring, wording and scale dependence; respondent role playing and instability over time or over respondents' moods" (Bernard and Taffesse 2014. p.190). Against this backdrop, however, what is suggested in the literature is that useful information could still be collected as long as extra care is taken during the design and implementation of surveys. For this study, we employed the survey instrument developed and tested for validity and reliability by Bernard and Taffesse (2014). To capture aspirations in four dimensions, the survey asks individuals a series of five questions regarding their income, wealth, social status and children's education. Specifically, the questions asked are:

(1) "What is the level of $[\ldots]$ you have at present?"

(2) "What is the level of $[\ldots]$ that you would like to achieve?"

(3) "What is the level of $[\ldots]$ that you think you will reach within ten years?"

(4) "What is the maximum level of [...] that a person can have in your village?"

(5) "What is the minimum level of [...] that a person can have in your village?"

The questions regarding own current level, village maximum and village minimum are intended to serve as benchmarks against which respondents would state their aspired level. The question on the expected level is intended to guide respondents in differentiating their aspirations from their expectations. Further, to maintain data quality, we executed careful preparations before the survey. For example, highly experienced enumerators were recruited and trained. The survey questionnaire was translated into local language and both the English and Amharic versions were made available to the enumerators. In addition, as part of the training, we conducted both mock interviews among enumerators and fieldtested the questionnaire. Further, to ensure that respondents understood the questions and did not state their simple wishes when asked their aspirations, ${ }^{17}$ special

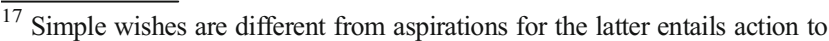
achieving them (Bernard et al. 2014)
}

care was applied during interviews, including probing and checking for consistency across responses. For example, after further clarification of the concept and definitions, respondents were allowed to change their responses if they thought that they had given "incorrect" responses.

On the calculation of the aspirations index: Since each dimension of aspirations may mean different things for different people (Leavy and Smith 2010), the weight or relative importance respondents place on each of the four dimensions was captured as explained next. First, respondents were given 20 beans and a piece of paper that pictured four squares. Each square was labelled with one of the four dimensions of the aspiration measures (i.e. income, wealth, social status or children's education). Then, respondents were asked to distribute all the 20 beans in the four squares according to their own assessment of the dimension's significance for them. The instructions were clear. For example, it was explained that no bean in a square means the respondent does not attach any importance to that particular indicator and, many beans in a square means the respondent attaches a significant importance to it. In what follows, we explain how the subjective weights given by the respondents were used in the calculation of an aggregate aspirations index.

As noted earlier, individuals aspire to achieve different things depending on their experiences and information set. Hence, relying on any single indicator may not suffice to measure aspirations. Yet, the four indicators are believed to be strongly correlated with each other and many other targets a person might want to achieve in their life. In this context, an aggregate index constructed from the four dimensions is believed to capture a broad array of life targets and serve as a strong proxy for aspirations. Hence, we calculated the aggregate index following Beaman et al. (2012) and Bernard and Taffesse (2014) using Eq. 1. The index was constructed by first normalising ${ }^{18}$ each dimension (i.e. by removing the average level for individuals in the same district, and then dividing this difference by the standard deviation for individuals in the same district) and multiplying the result by the weight each individual gives to each of the four indicators. Summing across the weighted average of the four normalized outcomes provides an aggregate aspirations index.

\footnotetext{
${ }^{18}$ Since attitudinal measures such as aspirations are likely to be measured with errors, normalization would help smooth out errors at the individual level. Further, normalization also makes individual indicators unit free, a prerequisite for aggregation
} 
Table 8 Summary statistics of variables used in the regressions $(N=375)$

\begin{tabular}{|c|c|c|c|c|}
\hline Variable & Mean & Std. Dev & Min & Max \\
\hline Per-capita calorie consumption & 3034.94 & 1398.42 & 657.6 & $10,324.6$ \\
\hline FCS & 70.63 & 18.25 & 21 & 107 \\
\hline HDDS & 8.60 & 1.38 & 5 & 11 \\
\hline HFIAS score & 0.469 & 1.904 & 0 & 16 \\
\hline Aspirations Head & 0.161 & 0.608 & -1.724 & 3.724 \\
\hline Aspirations Spouse $(n=320)$ & -0.162 & 0.577 & -2.695 & 2.919 \\
\hline Female hh head, $(1 / 0)^{\mathrm{a}}$ & 0.101 & 0.302 & 0 & 1 \\
\hline HH head Age $<31,(1 / 0)^{\mathrm{a}}$, (Ref.) & 0.058 & 0.235 & 0 & 1 \\
\hline HH head Age31-50, $(1 / 0)^{\mathrm{a}}$ & 0.493 & 0.501 & 0 & 1 \\
\hline HH head Age above 51, $(1 / 0)^{\mathrm{a}}$ & 0.443 & 0.497 & 0 & 1 \\
\hline Spouse Age $<31,(1 / 0)^{\mathrm{a}}$, (Ref.) & 0.188 & 0.391 & 0 & 1 \\
\hline Spouse Age $31-50,(1 / 0)^{\mathrm{a}}$ & 0.632 & 0.483 & 0 & 1 \\
\hline Spouse Age above 51, $(1 / 0)^{\mathrm{a}}$ & 0.169 & 0.375 & 0 & 1 \\
\hline Head education: $0,(1 / 0)^{\mathrm{a}}$, (Ref.) & 0.331 & 0.471 & 0 & 1 \\
\hline Head education: $1-4,(1 / 0)^{\mathrm{a}}$ & 0.179 & 0.384 & 0 & 1 \\
\hline Head education: $5-8,(1 / 0)^{\mathrm{a}}$ & 0.291 & 0.455 & 0 & 1 \\
\hline Head education: $8+,(1 / 0)^{\mathrm{a}}$ & 0.2 & 0.401 & 0 & 1 \\
\hline Spouse education: $0,(1 / 0)^{\mathrm{a}}$, (Ref.) & 0.5 & 0.501 & 0 & 1 \\
\hline Spouse education: $1-4,(1 / 0)^{\mathrm{a}}$ & 0.215 & 0.412 & 0 & 1 \\
\hline Spouse education: $5-8,(1 / 0)^{\mathrm{a}}$ & 0.185 & 0.389 & 0 & 1 \\
\hline Spouse education: $8+,(1 / 0)^{\mathrm{a}}$ & 0.099 & 0.300 & 0 & 1 \\
\hline HH size $(\ln )$ & 1.842 & 0.398 & 0 & 2.773 \\
\hline Dependency ratio & 0.389 & 0.211 & 0 & 1 \\
\hline HH has off-farm income, $(1 / 0)^{\mathrm{a}}$ & 0.488 & 0.501 & 0 & 1 \\
\hline HH head in business/wage labor, $(1 / 0)^{\mathrm{a}}$ & 0.325 & 0.469 & 0 & 1 \\
\hline Spouse in business/wage labor, $(1 / 0)^{\mathrm{a}}$ & 0.262 & 0.440 & 0 & 1 \\
\hline Change in per capita income (2006-10) in ETB & -813.016 & 1469.747 & -8774.76 & 6343.799 \\
\hline Income per-adult equiv. in ETB & 3310.824 & 2925.207 & 6.049137 & $24,258.94$ \\
\hline Value of assets (ln) in ETB & 8.613 & 1.317 & 4.094345 & 13.265 \\
\hline Livestock holding (TLU) & 8.066 & 5.250 & 0 & 35.052 \\
\hline Land in ha(ln) & 0.917 & 0.628 & -1.16475 & 2.822 \\
\hline Too much rain or flood, $(1 / 0)^{\mathrm{a}}$ & 0.088 & 0.284 & 0 & 1 \\
\hline Livestock diseases, $(1 / 0)^{\mathrm{a}}$ & 0.083 & 0.276 & 0 & 1 \\
\hline Increased input prices, $(1 / 0)^{\mathrm{a}}$ & 0.109 & 0.312 & 0 & 1 \\
\hline Death or loss of livestock, $(1 / 0)^{\mathrm{a}}$ & 0.093 & 0.291 & 0 & 1 \\
\hline Illness of head/spouse, $(1 / 0)^{\mathrm{a}}$ & 0.091 & 0.288 & 0 & 1 \\
\hline Illness of other family, $(1 / 0)^{\mathrm{a}}$ & 0.093 & 0.291 & 0 & 1 \\
\hline Road (minutes)(ln) & 2.143 & 2.120 & -6.908 & 4.788 \\
\hline Market(minutes)(ln) & 3.812 & 0.941 & 0.001 & 5.598 \\
\hline Adda-Lume, $(1 / 0)^{\mathrm{a}}$ & 0.328 & 0.470 & 0 & 1 \\
\hline Bako-Sire, $(1 / 0)^{\mathrm{a}}$ & 0.339 & 0.474 & 0 & 1 \\
\hline Hitossa-Tiyo, $(1 / 0)^{\mathrm{a}}$ & 0.333 & 0.472 & 0 & 1 \\
\hline
\end{tabular}

All data are from our 2014 survey, except when otherwise specified. $n$ simply reflects sample size of the spouse ${ }^{a}$ Binary outcome 
Open Access This article is distributed under the terms of the Creative Commons Attribution 4.0 International License (http:// creativecommons.org/licenses/by/4.0/), which permits unrestricted use, distribution, and reproduction in any medium, provided you give appropriate credit to the original author(s) and the source, provide a link to the Creative Commons license, and indicate if changes were made.

\section{References}

Abay, K., \& Hirvonen, K. (2016). Does market access mitigate the impact of seasonality on child growth? Panel data evidence from Northern Ethiopia. Ethiopia Strategy Support Program, Working Paper 85. IFPRI-ESSP.

Angrist, J.D., \& Pischke, J.S. (2009). Mostly harmless econometrics: an empiricist's companion. Princeton, NJ: Princeton University Press.

Appadurai, A. (2004). The capacity to aspire: Culture and the terms of recognition. In V. Rao \& M. Walton (Eds.), Culture and Public Action (pp. 59-84). Stanford: Stanford University Press.

Aredo, D., Tsegaye, W., La Rovere, R. \& Mwangi, W. (2008). Methodology: Impact Assessment (IA) Project - Ethiopia. CIMMYT/SG 2000, Monitoring and Impact Assessment (IA), Ethiopia. Nippon IA Research Report No. 1. Memo.

Asenso-Okyere, K., Chiang, C., Thangata, P., Andam, K., \& Mekonnen, D. A. (2011). Understanding the interaction between farm labor productivity, and health and nutrition: a survey of the evidence. Journal of Development and Agricultural Economics, 3(3), 80-90.

Asenso-Okyere, K., Mekonnen, D. A., \& Zerfu, E. (2013). Determinants of Food Security in Selected Agro-pastoral Communities of Somali and Oromia Regions, Ethiopia. Journal of Food Science and Engineering, 3, 453-471.

Bandura, A. (2009). Social cognitive theory goes global. The psychologist, 22(6), 504-506.

Barrett, C. B. (2010). Measuring Food Insecurity. Science. doi:10.1126 /science.1182768.

Beaman, L., Duflo, E., Pande, R., \& Topalova, P. (2012). Female Leadership Raises Aspirations and Educational Attainment for Girls: A Policy Experiment in India. Science. doi:10.1126 /science.1212382.

Benson, T. (2004). Africa's food and nutrition security situation: where are we and how did we get here? 2020 discussion paper 37. Washington, DC: International Food Policy Research Institute.

Berhane, G., Hoddinott, J., Kumar, N., \& Taffesse, A. S. (2011). The Impact of Ethiopia's Productive Safety Nets and Household Asset Building Programme: 2006-2010. Washington, DC: IFPRI.

Berhane, G., Gilligan, D. O., Hoddinott, J., Kumar, N., \& Taffesse, A. S. (2014). Can Social Protection Work in Africa? The Impact of Ethiopia's Productive Safety Net Programme. Economic Development and Cultural Change, 63(1), 1-26.

Bernard, T., \& Taffesse, A.S. (2012). Measuring aspirations: discussion and example from Ethiopia. International Food Policy Research Institute, Discussion Paper 1190. IFPRI

Bernard, T., \& Taffesse, A. S. (2014). Aspirations: An Approach to Measurement with Validation Using Ethiopian Data. Journal of African Economies, 23(2), 189-224.

Bernard, T., Taffesse, A. S., \& Dercon, S. (2008). Aspirations failure and well-being outcomes in Ethiopia: towards an Empirical Exploration. Oxford: Paper presented at Improving Institutions for Growth Workshop.

Bernard, T., Dercon, S., Taffesse, A.S., (2011). Beyond Fatalism-an empirical exploration of self-efficacy and aspirations failure in Ethiopia. International Food Policy Research Institute, Discussion Paper 1101
Bernard, T., Dercon, S., Orkin, K., \& Taffesse, A.S. (2014). The future in mind: aspirations and forward-looking behavior in Rural Ethiopia. CSAE Working Paper WPS/2014-16.

Christiaensen, L., \& Demery, L. (2007). Down to Earth: agriculture and poverty reduction in Africa. Washington, DC: The World Bank.

Clay, D. C., Molla, D., \& Habtewold, D. (1999). Food Aid Targeting in Ethiopia: A Study of Who Needs It and Who Gets It. Food Policy, 24(4), 391-409.

Coates, J., Swindale, A., \& Bilinsky, P. (2007). Household food insecurity access scale (HFIAS) for measurement of food access: indicator guide. Version 3. Washington, D.C.: Food and Nutrition Technical Assistance Project (FANTA), Academyfor Educational Development.

Coll-Black, S., Gilligan, D.O., Hoddinott, J., Kumar, N., Taffesse, A.S., \& Wiseman, W. (2011). Targeting food security interventions when "Everyone is poor": the case of Ethiopia's productive safety net programme. Ethiopia Strategy Support Program II, Working Paper 24. IFPRI-ESSP.

Dalton, P. S., Ghosal, S., \& Mani, A. (2016). Poverty and Aspirations Failure. The Economic Journal, 126(590), 165-188.

Dercon, S., \& Krishnan, P. (2000). In Sickness and in Health: Risk Sharing within Households in Rural Ethiopia. Journal of Political Economy, 108(4), 688-727.

Devereux, S. (2000). Food insecurity in Ethiopia, A discussion paper for DFID. IDS Sussex.

Dorosh, P. A., \& Rashid, S. (2012). Introduction. In P. A. Dorosh \& S. Rashid (Eds.), Food and agriculture in Ethiopia: progress and policy challenges (pp. 1-20). Philadelphia: Published for the International Food Policy Research Institute, University of Pennsylvania Press.

Ethiopia Humanitarian Requirements Document (EHRD) (2016). Joint government and humanitarian partners' document. http://www. unicef.org/ethiopia/ECO Ethiopia HRD 2016.pdf. Accessed 15 Jan 16.

FAO. (2002). The state of food insecurity in the World 2001. FAO: Rome.

FAO, IFAD and WFP. (2014). The State of Food Insecurity in the World 2014. Strengthening the enabling environment for food security and nutrition, Rome, FAO

FAO, IFAD and WFP. (2015). The state of food insecurity in the World 2015. Meeting the 2015 International Hunger Targets: Taking Stock of Uneven Progress. Rome: FAO.

Feleke, S. T., Kilmer, R. L., \& Gladwin, C. H. (2005). Determinants of Food Security in Southern Ethiopia at the Household Level. Agricultural Economics, 33(3), 351-363.

Galab, S., Vennam, U., Komanduri, A., Benny, L., \& Georgiadis, A. (2013). The impact of parental aspirations on private school enrolment: evidence from Andhra Pradesh, India. Working Paper 97, YoungLives.

Ghosal, S., Jana, S., Mani, A., Mitra, S., \& Roy, S. (2013). Sex workers, stigma and self-belief: evidence from a psychological training program in India. Working paper, University of Warwick, U.K

Gilligan, D. O., \& Hoddinott, J. (2007). Is there Persistence in the Impact of Emergency Food Aid? Evidence on Consumption, Food Security, and Assets in Rural Ethiopia. American Journal of Agricultural Economics, 89(2), 225-242.

Gilligan, D. O., Hoddinott, J., \& Taffesse, A. S. (2009). The Impact of Ethiopia's Productive Safety Net Programme and its Linkages. Journal of Development Studies, 45(10), 1684-1706.

Goux, D., Gurgand, M., \& Maurin, E. (2014). Adjusting your dreams? The effect of school and peers on dropout behaviour. IZA Discussion Paper 7948, Bonn.

Government of the Federal Democratic Republic of Ethiopia (GFDRE). (2007). Graduation guidance note. Addis Ababa: Food Security Coordination Directorate, Ministry of Agriculture and Rural Development. 
Government of the Federal Democratic Republic of Ethiopia (GFDRE). (2009). Food Security programme, 2010-2014. Addis Ababa: Ministry of Agriculture and Rural Development.

Jones, A. D., Ngure, F. M., Pelto, G., \& Young, S. L. (2013). What are we assessing when we measure food security? A compendium and review of current metrics. Advances in Nutrition, 4, 481-505.

Kosec, K., Hameed, M., Hausladen, S., (2012). Aspirations in rural Pakistan: an empirical analysis. Pakistan Strategy Support Program, Working Paper 009, International Food Policy Research Institute.

Leavy, J., \& Smith, S. (2010). Future farmers: youth aspirations, expectations and life choices. Discussion Paper 013, Future Agricultures.

Mekonnen, D.A., \& Gerber, N. (2016). The effect of aspirations on agricultural innovations in rural Ethiopia. ZEF Discussion Papers on Development Policy No. 214. University of Bonn.

Ministry of Finance and Economic Development (MoFED) (2013). Development and poverty in Ethiopia 1995/96-2010/11. Addis Ababa, Ministry of Finance and Economic Development.

Negatu, W. (2004). Reasons for food insecurity of farm households in South Wollo, Ethiopia: explanations at grassroots. BASIS CRSP. Madison, WI: Department of Agricultural and Applied Economics, University of Wisconsin-Madison.

Payne, J. W., Laughhunn, D. J., \& Crum, R. (1980). Translation of gambles and aspiration level effects in risky choice behavior. Management Science, 26, 1039-1060.

Payne, J. W., Laughhunn, D. J., \& Crum, R. (1981). Note-further tests of aspiration level effects in risky choice behavior. Management Science, 27(8), 953-958.

Quisumbing, A. R. (2003). Food aid and child nutrition in Rural Ethiopia. FCND Discussion Paper No. 158, International Food Policy Research Institute.

Ray, D. (2006). Aspirations, poverty and economic change. In A. V. Banerjee, R. Benabou, \& D. Mookherjee (Eds.), Understanding Poverty. Oxford: Oxford University Press.

Serneels, P., \& Dercon, S. (2014). Aspirations, poverty and education: evidence from India. Working Paper 125. Young Lives. Oxford Department of International Development (ODID), University of Oxford. ISBN: 978-1-909403-39-0.

Strauss, J., \& Thomas, D. (1995). Human resources: empirical modelling of household and family decisions. Handbook of Development Economics, 3(Part A), 1883-2023.

Swindale, A., \& Bilinsky, P. (2006). Household Dietary Diversity Score (HDDS) for measurement of household food access: indicator guide. Washington, DC: VERSION 2, Food and Nutrition Technical Assistance (FANTA).

Tafesse, G. (2005). The contributions of agricultural growth to poverty reduction in Ethiopia. Ethiopian Journal of Economics, 14(1), 1-26.

von Braun, J., \& Olofinbiyi, T. (2007). Famine and food insecurity in Ethiopia. In P. Pinstrup-Andersen \& F. Cheng (Eds.), Case studies in food policy for developing countries: policies for health, nutrition, food consumption, and poverty. Ithaca: Cornell University Press.

Wiesmann, D., Bassett, L., Benson, T., \& Hoddinott, J. (2009). Validation of the world food programme's food consumption score and alternative indicators of household food security. IFPRI Discussion Paper 00870.
World Bank. (2013). Ethiopia's Productive Safety Net Program (PSNP) integrating disaster and climate risk management: case study. Washington DC: World Bank.

World Bank. (2016). Ethiopia's great run: the growth acceleration and how to pace it. Washington, D.C.: World Bank Group.

World Food Programme (WFP) (2008). Food consumption analysis: calculation and use of the food consumption score in food security analysis. Technical Guidance Sheet. United Nations World Food Programme Headquarters, Rome, Italy

Yamano, T., Alderman, H., \& Christiaensen, L. (2005). Child growth, shocks, and food aid in rural Ethiopia. American Journal of Agricultural Economics, 87(2), 273-288.

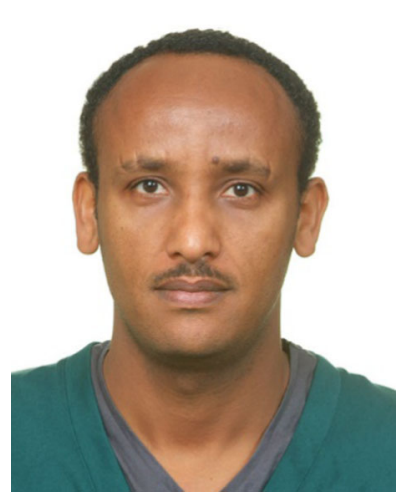

Daniel Ayalew Mekonnen is a postdoctoral researcher at the Department of Economic and Technological Change, Center for Development Research (ZEF), University of Bonn. Before conducting his doctoral studies, he had over 6 years of research experience working with the International Food Policy Research Institute in Addis Ababa, the MDGs/Poverty Analysis and Monitoring Section of the UN ECA, and the Ethiopia Ministry of Finance and Economic Development. His previous research examined the different aspects of agricultural and food policy issues including the provision of agricultural extension and health services and their linkages with wellbeing outcomes.

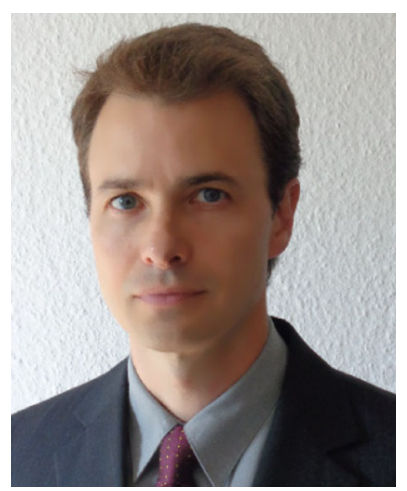

Nicolas Gerber has been senior researcher at the Center for Development Research (ZEF), University of Bonn since 2007. $\mathrm{He}$ received his $\mathrm{PhD}$ in Economics from the University of New South Wales, Australia. Over the last 15 years Nicolas has worked broadly on the management of biodiversity, land and water resources and their relations with poverty, food and nutrition security and health. He currently leads teams investigating the impacts of innovations and technological change in agriculture, at the household level and from a science system perspective. 